\title{
Effect of sulphasalazine and sulphapyridine on neutrophil superoxide production: role of cytosolic free calcium
}

\author{
Lars Kanerud, Ingiäld Hafström, Bo Ringertz
}

\begin{abstract}
As the neutrophil granulocyte plays an important part in rheumatoid inflammation the effect of sulphasalazine on neutrophil function was studied. The results show that sulphasalazine, and its metabolite sulphapyridine, inhibit neutrophil superoxide production elicited by the receptor mediated stimulus $\boldsymbol{N}$-formyl-methionyl-leucyl-phenylalanine (fMLP) and by the calcium ionophore A23187. This effect seems to be dependent on inhibition of intracellular $\mathrm{Ca}^{++}$increase as both substances reduce this increase upon cell activation with fMLP and A23187. Sulphasalazine and sulphapyridine do not inhibit superoxide production after stimulation with the ester phorbol myristate acetate, a stimulus response coupling which is independent of intracellular $\mathrm{Ca}^{++}$increase. The reported inhibition of superoxide generation may explain, at least partly, the antirheumatic property of sulphasalazine.
\end{abstract}

Sulphasalazine is now widely accepted as a disease modifying drug in the treatment of rheumatoid arthritis. ${ }^{1-5}$ The mechanisms by which sulphasalazine exerts its antirheumatic properties are largely unknown, however, and it is also unclear which part of the molecule is active.

Less than $30 \%$ of ingested sulphasalazine is absorbed in the small intestine. ${ }^{67}$ The remaining drug is cleaved by colonic bacteria into sulphapyridine and 5-aminosalicylic acid. ${ }^{689}$ Sulphapyridine is almost totally absorbed whereas 5aminosalicylic acid largely is retained in the colon and can only be detected in serum in very small amounts. ${ }^{7-10}$ In the colon 5-aminosalicylic acid is present in high concentrations and has been considered to be the therapeutic moiety of sulphasalazine in ulcerative colitis. ${ }^{11} 12$

In rheumatoid arthritis, on the other hand, it has during the last years been proposed that sulphapyridine or sulphasalazine, or both, are responsible for the antirheumatic activity. ${ }^{13} 14$ Suggested explanations for this activity include antibacterial effect in the colon ${ }^{15}$ or immunosuppressive activity. ${ }^{16-19}$ Sulphasalazine also interferes with prostaglandin metabolism. ${ }^{2021}$ A further proposal is that sulphasalazine or sulphapyridine affects neutrophil function.

Neutrophils play an important part in the pathogenesis of the inflammatory process in rheumatoid arthritis. Thus upon activation these cells release lysosomal enzymes and reactive oxygen radicals, ${ }^{22-24}$ which can provoke tissue destruction and mediate abnormal immune reactions. ${ }^{25} 26$ It has been shown that neutrophil superoxide production as well as chemotaxis elicited by the synthetic tripeptide $N$-formylmethionyl-leucyl-phenylalanine (fMLP) were reduced by sulphasalazine, ${ }^{27} 28$ and that this reduction might depend on sulphasalazine inhibiting the binding of $\mathrm{M}$ MP to its receptors on neutrophils. ${ }^{27}$ Furthermore, sulphasalazine or sulphapyridine decreased superoxide production and lysosomal enzyme release in response to serum coated zymosan and immune complexes. ${ }^{28-30}$ Whether these last effects were due to inhibition of particle binding has not been studied. Consequently, it is unclear if sulphasalazine affects neutrophil functions merely by inhibiting binding of fMLP and particles to its receptors or if sulphasalazine also affects intrinsic neutrophil properties. It was thus of interest to investigate further the way in which sulphasalazine and sulphapyridine affect neutrophil function. For that purpose neutrophil superoxide production was stimulated, by, in addition to fMLP, the calcium ionophore A23187 and the tumour promoting ester phorbol myristate acetate (PMA), agents with different triggering mechanisms for stimulation of neutrophil NADPH-oxidase. ${ }^{31}{ }^{32}$ The results are discussed in relation to the initiating mechanisms of the respiratory burst, especially with reference to the noted effects of sulphasalazine and sulphapyridine on intracellular $\mathrm{Ca}^{++}$mobilisation.

\section{Materials and methods}

NEUTROPHIL ISOLATION

Peripheral blood neutrophils from normal human subjects were isolated by Percoll discontinuous gradient centrifugation ${ }^{33}$ and resuspended in Hanks's balanced salt solution (HBSS) without albumin. This procedure yielded preparations containing $>95 \%$ of neutrophils.

NEUTROPHIL FUNCTION ASSAYS

Where indicated, neutrophils were preincubated with sulphasalazine or sulphapyridine dissolved in HBSS, at concentrations of $1 \mu \mathrm{mol} / \mathrm{l}$ to $1 \mathrm{mmol} / 1$ for 10 minutes at $37^{\circ} \mathrm{C}$. At these concentrations sulphasalazine and sulphapyridine did not affect cell viability measured by trypan blue exclusion. As Nielsen et al have shown that the inhibitory effect of sulphasalazine on neutrophil function occurs rapidly and is almost maximal after 10 minutes' incubation, ${ }^{34}$ this incubation time was chosen.

Superoxide generation

Superoxide production by neutrophils was 
determined spectrophotometrically by monitoring superoxide dismutase inhibitable reduction of cytochrome $c$ as described previously. ${ }^{35}$ Briefly, to neutrophils $\left(2.5 \times 10^{6}\right.$ cells $\left./ \mathrm{ml}\right)$ in $2 \mathrm{ml}$ HBSS was added $50 \mu \mathrm{M}$ ferricytochrome $c$ before stimulation with $0 \cdot 1 \mu \mathrm{M}$ fMLP, $5 \mu \mathrm{M}$ A23187, or $10 \mu \mathrm{M}$ PMA, and the change in absorbance at $550 \mathrm{~nm}$ was measured continuously at $37^{\circ} \mathrm{C}$ in a Perkin-Elmer Lambda 7 spectrophotometer. Sulphasalazine or sulphapyridine was present during stimulation or cells were first incubated with sulphasalazine/sulphapyridine and then washed before addition of cytochrome $c$ and stimulus. Reduction of cytochrome $c$ stimulated by fMLP and A23187 was measured at the end point of the reactions. The results for PMA were calculated as the linear rate of cytochrome $c$ reduction measured between 3 and 5.5 minutes after stimulation. As the sensitivity of neutrophils to stimulation varies from donor to donor the effect of sulphasalazine and sulphapyridine is expressed as the percentage of superoxide produced by control neutrophils incubated without sulphasalazine or sulphapyridine.

\section{Cytosolic free $\mathrm{Ca}^{++}$concentration}

To measure cytosolic free $\mathrm{Ca}^{++}$concentration the fluorescent probe fura- 2 was used because of its brighter fluorescence and improved selectivity to $\mathrm{Ca}^{++}$over other divalent cations, compared with-for example, Quin-2.36 Neutrophils $\left(5 \times 10^{6}\right.$ cells $\left./ \mathrm{ml}\right)$ in HBSS supplemented with 20 mM $N$-2-hydroxyethylpiperazine- $N^{\prime}$-2-ethanesulphonic acid (HEPES) pH 7.4 were loaded with $0.5 \mu \mathrm{M}$ fura-2AM (fura-2-tetra-acetomethoxy ester) for 30 minutes at $37^{\circ} \mathrm{C}$. The cells were then washed twice and resuspended in HBSS with HEPES in a concentration of $2.5 \times 10^{6}$ cells $/ \mathrm{ml}$ before incubation with sulphasalazine/sulphapyridine or buffer for 10 minutes. Subsequently, fMLP $0 \cdot 1 \mu \mathrm{mol} / 1$ or ionomycin 2 $\mu \mathrm{mol} / \mathrm{l}$ was added as stimulus. Ionomycin was used instead of A23187 as the intrinsic fluorescence of the latter interferes with the emission spectra of the fura- 2 complex. Fluorescence measurements were performed in a Hitachi model F-3000 spectrofluorometer with quartz cuvettes at a constant temperature of $37^{\circ} \mathrm{C}$ and with continuous stirring of cells. Excitation and emission wavelengths were 340 and $510 \mathrm{~nm}$ respectively. The system was controlled by addition of EGTA, TRIS buffer, Triton X-100, and $\mathrm{CaCl}_{2} \cdot{ }^{37}$ The calculated concentration of cytosolic free $\mathrm{Ca}^{++}$was: $\left[\mathrm{Ca}^{++}\right]=\mathbf{k d}\left(\mathrm{F}-\mathrm{F}_{\min }\right) /$ $\left.F_{\max }-F\right)$, where $F$ is the measured fluorescence, $F_{\min }$ the fluorescence after lysing the cells with Triton $X-100$, and $F_{\max }$ the fluorescence from calcium saturated dye. The $\mathrm{kd}$ value is 224 $\mathrm{nmol} / \mathrm{l}^{36}$

\section{Results}

SUPEROXIDE PRODUCTION

To study possible inhibitory effects of sulphasalazine and sulphapyridine the experiments were performed with optimal concentrations of the stimuli (fMLP 0.1 $\mu \mathrm{mol} / \mathrm{l}, \mathrm{A} 231875 \mu \mathrm{mol} / \mathrm{l}$, and PMA $10 \mu \mathrm{mol} / \mathrm{l})$, thereby achieving maximal response of neutrophil superoxide generation. Reduction of cytochrome $c$ stimulated by fMLP started immediately after addition of stimulus and ended within four to five minutes. Superoxide production elicited by A23187 also started immediately after addition of stimulus but the reaction lasted longer than for fMLP and often did not end until after 10 minutes. Superoxide production stimulated by PMA started after a lag period of approximately 1.5 minutes and the response was protracted.

When neutrophils were incubated with sulphasalazine, $10 \mu \mathrm{mol} / 1-0.5 \mathrm{mmol} / \mathrm{l}$, there was a significant reduction of superoxide production stimulated by fMLP and A23187. Sulphasalazine did not inhibit superoxide production when PMA was used as stimulus, however (fig 1).

Similarly, sulphapyridine inhibited fMLP and A23187 elicited superoxide production, but had no effect on PMA induced superoxide production (fig 2).

When neutrophils incubated with sulphasalazine for $\mathbf{1 0}$ minutes were washed free from sulphasalazine before stimulation with fMLP and A23187 inhibition of superoxide production was no longer observed. The inhibition by sulphapyridine was, however, partially irrever-

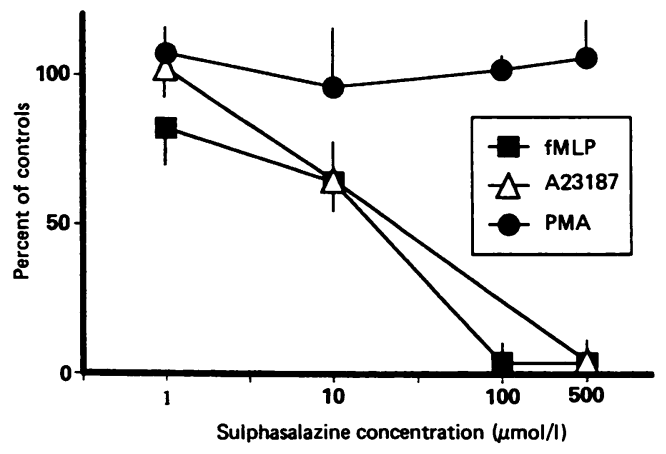

Figure 1: Effects of various concentrations of sulphasalazine on neutrophil superoxide production elicited by $f M L P 0 \cdot 1$ $\mu \mathrm{mol} / \mathrm{l}$, ionophore A23187 $5 \mu \mathrm{mol} / \mathrm{l}$, and PMA $10 \mu \mathrm{mol} / \mathrm{l}$. Neutrophils were incubated with sulphasalazine 1 umol/l to $0.5 \mathrm{mmol} / \mathrm{l}$ before being tested. Results are means and SEM of three to five experiments (different donors) and expressed as a percentage of control cells not exposed to any drug. $f M L P=N$-formyl-methionyl-leucyl-phenylalanine;

PMA = phorbol myristate acetate.

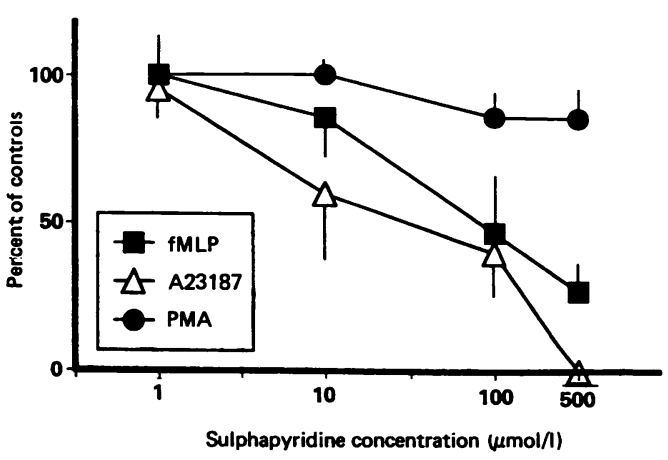

Figure 2: Effects of various concentrations of sulphapyridine on neutrophil superoxide production elicited by fMLP $0 \cdot 1$ $\mu \mathrm{mol} / \mathrm{l}$, iomophore A23187 $5 \mu \mathrm{mol} / \mathrm{l}$, and PMA $10 \mu \mathrm{mol} / \mathrm{l}$. Neutrophils were incubated with sulphapyridine 1 Mmol/l to $0.5 \mathrm{mmol} / \mathrm{l}$ before being tested. Results are means and SEM of three to five experiments (different donors) and expressed as a percentage of control cells not exposed to any drug. $f M L P=N$-formyl-methionyl-leucyl-phenylalanine; $P M A=$ phorbol myristate acetate. 
sible. Thus cells incubated with $0.5 \mathrm{mM}$ sulphapyridine after washing generated $64 \cdot 1$ (SEM $7 \cdot 2) \%$ superoxide upon fMLP stimulation and upon A23187 stimulation $58 \cdot 1$ (10.2)\% superoxide compared with control cells.

Sulphasalazine and sulphapyridine had no effect on basal cytochrome $c$ reduction. In addition, neither inhibited superoxide production by a cell free generating system of xanthine plus xanthine oxidase (data not shown). Therefore sulphasalazine and sulphapyridine did not exert their inhibitory effects on oxidative metabolism by scavenging superoxide anion directly.

INCREASE OF CYTOSOLIC $\mathrm{Ca}^{++}$CONCENTRATION As superoxide production elicited by both fMLP and ionophore was inhibited by sulphasalazine and sulphapyridine we next studied a common signal transduction event essential for ligand and calcium ionophore but not for PMA elicited neutrophil function. Consequently, we measured the effect of sulphasalazine or sulphapyridine on the ability of FMLP and of a calcium ionophore, ionomycin, to induce changes in neutrophil free $\mathrm{Ca}^{++}$. We used neutrophils loaded with fura-2, a dye that forms a fluorescent complex with $\mathrm{Ca}^{++}$. An increase in fluorescence upon stimulation of cells is considered to correlate with an increase of cytosolic free $\mathrm{Ca}^{++}$. Both fMLP 0.1 $\mu \mathrm{mol} / 1$ and ionomycin 2 $\mu \mathrm{mol} / \mathrm{l}$ rapidly increased the fluorescence and, thus, the cytosolic $\mathrm{Ca}^{++}$concentration. Neutrophils at rest had a cytosolic $\mathrm{Ca}^{++}$concentration of 70 (SEM 9) nmol/l, which upon cell activation with $\mathrm{fMLP}$ increased to 401 (15) $\mathrm{nmol} / \mathrm{l}$ and upon activation with ionomycin to 422 (38) $\mathrm{nmol} / \mathrm{l}$. The intention was to see if sulphasalazine $100 \mu \mathrm{mol} / \mathrm{l}$ and sulphapyridine $100 \mu \mathrm{mol} / \mathrm{l}$, which significantly inhibited superoxide production, inhibited this $\mathrm{Ca}^{++}$increase. Sulphasalazine $100 \mu \mathrm{mol} / \mathrm{l}$ had a slightly yellow colour, however, which interfered with the light emission. We instead used sulphasalazine $10 \mu \mathrm{mol} / \mathrm{l}$ as it was not feasible to wash sulphasalazine

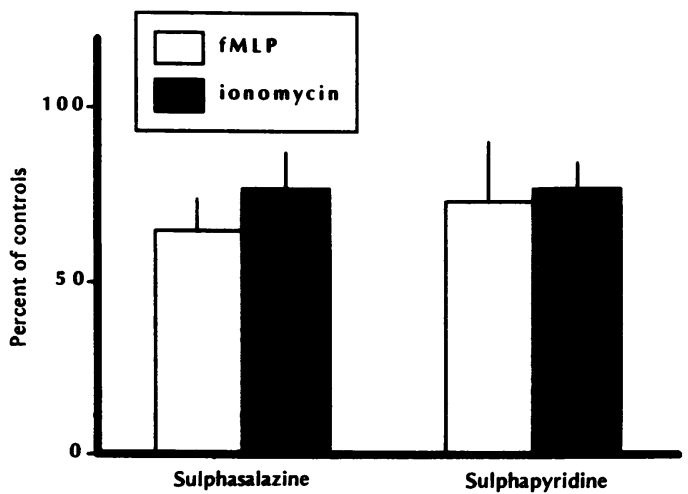

Figure 3: Effects of sulphasalazine and sulphapyridine on neutrophil intracellular $\mathrm{Ca}^{++}$increase elicited by $\mathrm{fMLPO}$. 1 umolll or ionomycin 2 umolll. Neutrophils were either incubated with sulphasalazine 10 umolll before stimulation or incubated with sulphapyridine 100 pmolll and then washed before addition of stimulus. Results are means and $S E M$ of four experiments and expressed as a percentage of control cells not exposed to any drug but otherwise similarly treated. $f M L P=N$-formyl-methionyl-leucyl-phenylalanine. away because of the shown reversible effect (see above). Sulphapyridine $100 \mu \mathrm{mol} / \mathrm{l}$ also interfered with the fluorescence, but as the effect on superoxide production was only partially reversible the cells were washed after incubation with sulphapyridine $100 \mu \mathrm{mol} / \mathrm{l}$ and thereafter stimulated with FMLP and ionophore.

The results showed that sulphasalazine 10 $\mu \mathrm{mol} / 1$ significantly inhibited both fMLP and ionomycin induced increase of cytosolic free $\mathrm{Ca}^{++}$. Sulphapyridine $100 \mu \mathrm{mol} / \mathrm{l}$ also inhibited both responses when cells were washed after incubation and before stimulation (fig 3).

\section{Discussion}

In this study we have shown that sulphasalazine and sulphapyridine inhibit superoxide production elicited by the tripeptide fMLP and the calcium ionophore A23187 in a dose dependent manner, and that they also inhibit mobilisation of cytosolic free $\mathrm{Ca}^{++}$induced by the same stimuli. Sulphasalazine and sulphapyridine do not, however, affect PMA elicited superoxide generation, a stimulus response coupling that is independent of increase of cytosolic free $\mathrm{Ca}^{++} .3839$

Neutrophils can be triggered to generate superoxide anions by a variety of stimuli, including the tripeptide $\mathrm{fMLP}$, calcium ionophores, and the tumour promoter PMA. The signal transduction pathways by which these stimuli activate the membrane oxidase are different, however (fig 4).

The inhibition of IMLP elicited superoxide generation by sulphasalazine and sulphapyridine

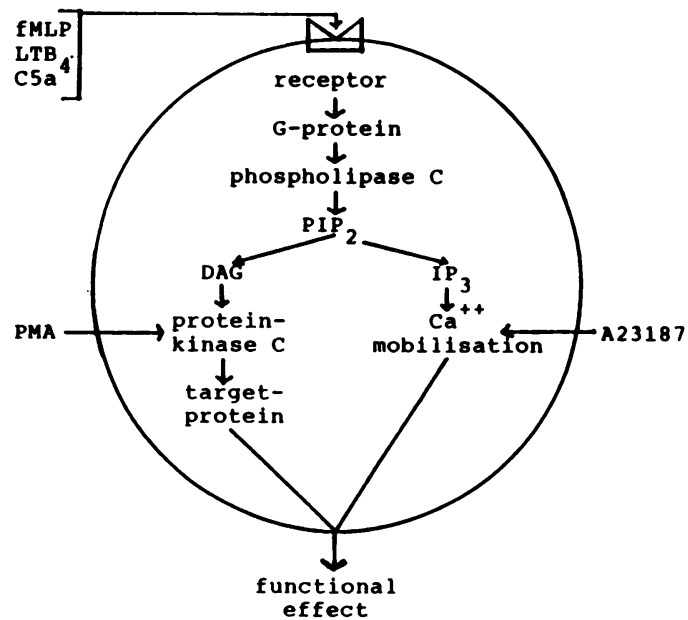

Figure 4: Schematic illustration of neutrophil activation: fMLP binds to a specific surface membrane receptor, which by guanine nucleotide binding stimulates phospholipase $C$ dependent phosphoinositol hydrolysis to generate inositol 1,4,5-triphosphate and diacylglycerol. Inositol 1,4,5-triphosphate causes release of $\mathrm{Ca}^{++}$from intracellular stores, whereas diacylglycerol activates protein kinase $C$, which are both suggested to be second messengers for eliciting functional responses - that is, activating the oxidase enzyme. Phorbol myristate acetate binds to cytosolic receptors, which are equivalent to protein kinase $C$, the occupancy of which activates the membrane oxidase, thereby eliciting superoxide production. fMLP $=N$-formyl-methionyl-leucylphenylalanine; $L T B_{4}=$ lewkotriene $B_{4} ; P I P_{2}=$ phosphoinositol diphosphate; $D A G=$ diacylglycerol; $P M A=$ phorbol myristate acetate; $I P_{3}=$ inositol $1,4,5$ triphosphate. 
shown here might theoretically be located at any step in the stimulus response coupling. One possibility is that the drugs inhibit binding of fMLP to its receptor, which has been reported earlier for sulphasalazine. ${ }^{27}$ The inhibition of superoxide generation may, however, not solely be attributed to inhibition of fMLP binding. Other mechanisms are probable because sulphasalazine and sulphapyridine also reduced superoxide release by A23187. The similar doseresponse curves for the effect of sulphasalazine and sulphapyridine on superoxide generation elicited by fMLP and A23187 suggest there may be a common block.

Calcium ionophores increase cytosolic free $\mathrm{Ca}^{++}$directly by transporting calcium into the cell, thus bypassing the initial steps for fMLP activation. The findings reported here that sulphasalazine and sulphapyridine inhibit increase of cytosolic $\mathrm{Ca}^{++}$induced by both FMLP and the calcium ionophore ionomycin indicate that they interfere with calcium mobilisation. According to earlier work, such a block of calcium redistribution may well explain the reduced oxidase activation. ${ }^{4041}$

Further support for the theory that sulphasalazine and sulphapyridine act by interfering with calcium mobilisation is that neither substance affected superoxide generation induced by PMA. Neutrophil functions stimulated by PMA are not associated with and not dependent on a rise in the level of intracellular free $\mathrm{Ca}^{++} .3839$

The fact that superoxide generation induced by PMA was unaffected by sulphasalazine and sulphapyridine indicates that these drugs do not impair the oxidase enzyme activity or reduce the amount of enzyme available. It also suggests that sulphasalazine and sulphapyridine do not have a direct oxy radical scavenging action. The other moiety of sulphasalazine, 5-aminosalicylic acid, is however, a known potent scavenger of free radicals, ${ }^{42}$ which implies that the effect of 5 -aminosalicylic acid on neutrophil oxidative metabolism cannot be analysed by this superoxide production assay.

A recent hypothesis is that sulphasalazine and sulphapyridine act as inhibitors of neutrophil lipoxygenase enzyme. When neutrophils are activated by FMLP and A23187, arachidonic acid is metabolised mainly by 5-lipoxygenase to 5-hydroxyeicosatetraenoic acid and leukotriene $\mathrm{B}_{4}{ }^{4344}$ It has been suggested that leukotriene $B_{4}$, which is an activator of neutrophils, is also an intracellular second messenger. ${ }^{45} \mathrm{~A}$ number of reports suggest that superoxide generation by receptor stimuli and A23187 is linked to arachidonic acid metabolism. ${ }^{46-48}$ On the other hand, PMA activation of the oxidase enzyme is independent, not only of intracellular calcium increase but also of arachidonic acid metabolism, ${ }^{49}$ and PMA can induce release of neither leukotriene $B_{4}$ nor other lipoxygenase products. ${ }^{50}$ An inhibitory effect on lipoxygenase enzyme might thus explain the demonstrated reductions by sulphasalazine and sulphapyridine on superoxide generation elicited by fMLP and A23187 but probably not the effect on calcium mobilisation. It might further explain the lack of effect on PMA elicited superoxide generation.
The effect of sulphasalazine and sulphapyridine on arachidonic acid metabolism has been investigated previously by a soybean lipoxygenase assay, ${ }^{5152}$ which indicated that sulphasalazine, but not sulphapyridine, inhibits the lipoxygenase enzyme. In a study with human neutrophils sulphasalazine, and to a lesser extent sulphapyridine, inhibited leukotriene $\mathrm{B}_{4}$ and 5-hydroxyeicosatetraenoic acid biosynthesis when cells were exposed to extracellular arachidonic acid and stimulated by A23187. ${ }^{53}$ Also, when arachidonic acid was incorporated into neutrophils before stimulation with $\mathrm{A} 23187$, sulphasalazine inhibited production of the two main 5-lipoxygenase products of arachidonic acid, leukotriene $B_{4}$ and 5-hydroxyeicosatetraenoic acid. ${ }^{34}$ The last two reports ${ }^{34} 53$ are difficult to intepret, as the reduced synthesis of lipoxygenase products was noted after stimulation with the calcium ionophore A23187. Our finding that sulphasalazine and sulphapyridine inhibit the very first step in calcium ionophore activation, the increase of cytosolic free $\mathrm{Ca}^{++}$, makes it likely that the following steps in the activation pathway also - that is, lipoxygenase activation, are inhibited. The reduced synthesis of lipoxygenase products might thus follow inhibition of calcium mobilisation, and need not indicate a direct inhibitory effect on the enzyme activity. The pure biochemical assays, however, indicate that sulphasalazine, but not sulphapyridine, inhibits lipoxygenase activity. ${ }^{51} 52$

It can thus be stated that sulphasalazine and sulphapyridine inhibit neutrophil superoxide generation induced by fMLP and A23187, an effect that probably depends mainly on inhibition of calcium mobilisation. Earlier reported inhibition of lipoxygenase activity may, however, contribute to the reduced neutrophil activity. Current knowledge indicates that superoxide radicals are associated with the pathogenesis of rheumatoid arthritis. The reported inhibition of superoxide generation by sulphasalazine and sulphapyridine may be one mechanism by which these substances reduce the inflammatory reaction in that disease.

We thank Mrs Ingegärd Friberg and Mrs Pia Spångberg for excellent technical assistance and Mrs Åsa Sagner for skilfu secretarial work. Sulphasalazine and sulphapyridine were a kind gift from Pharmacia, Sweden.

1 McConkey B, Amos R S, Butler E P, Crockson R A Crockson A P, Walsh L. Salazopyrin in rheumatoid arthritis. Agents Actions 1978; 8: 438-41.

2 McConkey B, Amos R S, Durham S, Forster P J G, Hubbal $\mathrm{S}$, Walsh $\mathrm{L}$. Sulphasalazine in rheumatoid arthritis. $\mathrm{Br} \mathrm{Med}$ f 1980; 280: 442-4.

3 Neumann V C, Grindulis K A, Hubball S, McConkey B, Wright V. Comparison between penicillamine and sulphasalazine in rheumatoid arthritis: Leeds Birmingham-trial. salazine in rheumatoid arthritis:

4 Pullar T, Hunter J A, Capell H A. Sulphasalazine in rheumatoid arthritis: a double blind comparison of sulphasalazine with placebo and sodium aurothiomalate. $\mathrm{BrMed}$ f 1983; 287: 1102-4.

5 Pinals R S, Kaplan S B, Lawson J G, Hepburn B Sulfasalazine in rheumatoid arthritis. A double blind placebo-controlled trial. Arthritis Rheum 1986; 29: 427-34.

6 Schröder H, Campbell D E S. Absorption, metabolism, and excretion of salicylazosulfapyridine in man. Clin Pharmaco Ther 1972; 13: 539-51.

7 Azad Khan A K, Truelove S C, Aronson J K. The disposition and metabolism of sulphasalazine (salicylazosulphapyridine) in man. Br $\mathcal{~ C ~ C l i n ~ P h a r m a c o l ~ 1 9 8 2 ; ~ 1 3 : ~ 5 2 3 - 8 . ~}$

8 Peppercorn M A, Goldman P. The role of intestinal bacteria in the metabolism of salicylazosulfapyridine. $\mathcal{F}$ Pharmacol in the metabolism of salicyla

9 Das K M, Eastwood M A, McManus J P A, Sircus W. The role of the colon in the metabolism of salicylazosulphapyridine. Scand $\mathcal{F}$ Gastroenterol 1974; 9: 137-41. 
10 Peppercorn M A, Goldman P. Distribution studies of salicylazosulfapyridine and its metabolites. Gastroenterolog 1973; 64: $240-5$.

11 Azad Khan A K, Piris J, Truelove S C. An experiment to determine the active therapeutic moiety of sulphasalazine. Lancet 1977; ii: 892-5.

12 Van Hees P A M, Bakker J H, Van Tongeren J H M. Effect of sulphapyridine, 5-aminosalicylic acid and placebo in patients with idiopathic proctitis: a study to determine the active therapeutic moiety of sulphasalazine. Gut 1980; 21 : 632-5.

13 Pullar T, Hunter J A, Capell H A. Which component of sulphasalazine is active in rheumatoid arthritis? $\mathrm{Br}$ Med 1985; 290: 1535-8.

14 Neumann V C, Taggart A J, Le Gallez P, Astbury C, Hill J, Bird $H$ A. A study to determine the active moiety of sulphasalazine in rheumatoid arthritis. $\mathcal{F}$ Rheumatol 1986; 13: $285-7$

15 Neuman V C, Shinebaum R, Cooke E M, Wright V. Effects of sulphasalazine on faecal flora in patients with rheumatoid arthritis: a comparison with penicillamine. Br $\mathcal{J}$ Rheumatol 1987; 26: 334-7.

16 Holm G, Perlmann P. The effect of antimetabolites on the cytotoxicity by human lymphocytes. In: Dausset J, et al, eds. Advances in transplantation. Copenhagen: Munksgaard, 1968: 155-61.

17 Sheldon P J, Webb C, Grindulis K A. Sulphasalazine in rheumatoid arthritis: pointers to a gut-mediated immune rheumatoid arthritis: pointers to a gut-

18 Symmons D P M, Salmon M, Farr M, Bacon P A. Sulfasalazine treatment and lymphocyte function in patients with rheumatoid arthritis. $\mathcal{F}$ Rheumatol 1988; 15: 575-9.

19 Comer S S, Jasin H E. In vitro immunomodulatory effects of sulfasalazine and its metabolites. I Rheumatol 1988; 15 580-6.

20 Smith P R, Dawson D J, Swan C H J. Prostaglandin synthetase activity in acute ulcerative colitis: effects of treatment with sulphasalazine, codeine phosphate and prednisolone. Gut 1979; 20: 802-5.

21 Hoult J R S, Moore P K. Effects of sulphasalazine and its metabolites on prostaglandin synthesis, inactivation and
actions on smooth muscle. Br $f$ Pharmacol 1980; 68: actions

22 Weissmann G, Zurier R B, Spieler P J, Goldstein I M. Mechanisms of lysosomal enzyme release from leukocytes exposed to immune complexes and other particles. $\mathcal{f}$ Exp Med 1971; 134: 149s-65s

23 Goldstein I M, Roos D, Kaplan H B, Weissmann G. Complement and immunoglobulins stimulate superoxide production by human leukocytes independently of phagocytosis. F Clin Invest 1975; 56: 1155-63.

24 Lehmeyer J E, Snyderman R, Johnston Jr R B. Stimulation of neutrophil oxidative metabolism by chemotactic peptides: influence of calcium ion concentration and cytochalasin B influence of calcium ion concentration and cytochalasin $B$
and comparison with stimulation by phorbol myristate and comparison with stimulatio

25 McCord J M, Fridovich I. The biology and pathology of oxygen radicals. Ann Intern Med 1978; 89: 122-7.

26 Halliwell B. Hypothesis: production of superoxide, hydrogen peroxide and hydroxyl radicals by phagocytic cells: A cause of chronic inflammatory disease? Cell Biol Int Rep 1982; 6: 529-42.

27 Stenson W F, Mehta J, Spilberg I. Sulfasalazine inhibition of binding of $\mathrm{N}$-formyl-methionyl-leucyl-phenylalanine (fMLP) to its receptor on human neutrophils. Biochem Pharmacol 1984; 33: 407-12.

28 Neal T M, Winterbourn C C, Vissers M C M. Inhibition of neutrophil degranulation and superoxide production by neutrophil degranulation and superoxide production

29 Molin L, Stendahl $\mathrm{O}$. The effect of sulfasalazine and its active components on human polymorphonuclear leukocyte function in relation to ulcerative colitis. Acta Med Scand 1979; 206: 451-7.

30 Miyachi Y, Yoshioka A, Imamura S, Niwa Y. Effect of sulphasalazine and its metabolites on the generation of reactive oxygen species. Gut 1987; 28: 190-5.

31 Babior B M. The respiratory burst of phagocytes. $f$ Clin Invest 1984; 73: 599-601.
32 Hurst N P. Molecular basis of activation and regulation of the phagocyte respiratory burst. Ann Rheum Dis 1987; 46: 265-72.

33 Ringertz B, Palmblad J, Rådmark O, Malmsten C. Leukotriene-induced neutrophil aggregation in vitro. FEBS Let 1982; 147: 1-3.

34 Nielsen O H, Bukhave K, Elmgreen J, Ahnfelt-Rönne I Inhibition of 5-lipoxygenase pathway of arachidonic acid metabolism in human neutrophils by sulfasalazine and 5 aminosalicylic acid. Dig Dis Sci 1987; 32: 577-82.

35 Seligmann B E, Fletcher M P, Gallin J I. Histamine modulation of human neutrophil oxidative metabolism locomotion, degranulation, and membrane potential changes. F Immunol 1983; 130: 1902-9.

36 Grynkiewiez G, Poenie M, Tsien R Y. A new generation of $\mathrm{Ca}^{2+}$ indicators with greatly improved fluorescence properties. F Biol Chem 1985; 260: 3440-50.

37 Metcalf J A, Gallin J I, Nauseef W M, Root R K. Laboratory manual of neutrophil function. New York: Raven Press 1986: $74-7$.

38 Sha'afi R I, White J R, Molski T F P, et al. Phorbol 12 myristate 13-acetate activates rabbit neutrophils without an apparent rise in the level of intracellular free calcium. Biochem Biophys Res Commun 1983; 114: 638-45.

39 Di Virgilio F, Lew D P, Pozzan T. Protein kinase C activation of physiological processes in human neutrophils at vanishingly small cytosolic $\mathrm{Ca}^{2+}$ levels. Nature $1984 ; 310$ at vanishin.

40 Smolen J E. Lag period for superoxide anion generation and lysosomal enzyme release from human neutrophils: effects of calcium antagonists and anion channel blockers. $\mathcal{f ~} \mathrm{La}$ Clin Med 1984; 104: 1-10.

41 Lew P D, Wollheim C B, Waldvogel F A, Pozzan T Modulation of cytosolic-free calcium transients by changes in intracellular calcium-buffering capacity: correlation with exocytosis and $\mathrm{O}_{2}$ production in human neutrophils. $\mathrm{F}$ Cell Biol 1984; 99: 1212-20.

42 Ahnfelt-Rönne I, Haagen Nielsen $O$. The antiinflammatory moiety of sulfasalazine, 5 -aminosalicylic acid, is a radical moiety of sulfasalazine, 5-aminosalicylic acid

43 Borgeat $P$, Samuelsson $B$. Transformation of arachidonic acid by rabbit polymorphonuclear leukocytes. $\mathcal{F}$ Biol Chem 1979 254: $2643-6$.

44 Stenson W F, Parker C W. Metabolism of arachidonic acid in ionophore-stimulated neutrophils. F Clin Invest 1979; 64: 1457-65

45 Palmblad J, Gyllenhammar H, Lindgren J Å, Malmsten C L. Effects of leukotrienes and f-met-leu-phe on oxidative metabolism of neutrophils and eosinophils. F Immunol 1984; 132: 3041-5.

46 Curnutte J T . Activation of human neutrophil nicotinamide adenine dinucleotide phosphate, reduced (triphosphoadenine dinucleotide phosphate, reduced (triphosphopyridine nucleotide, reduced) oxidase by arachidon

47 Sakata A, Ida E, Tominaga M, Onoue K. Arachidonic acid acts as an intracellular activator of NADPH-oxidase in Fcreceptor-mediated superoxide generation in macrophages. f Immunol 1987; 138: 4353-9.

48 McPhail L C, Clayton C C, Snyderman R. A potential second messenger role for unsaturated fatty acids: activation of

49 Maridonneau-Parini I, Tringale S M, Tauber A I. Identification of distinct activation pathways of the human neutro-
phil NADPH-oxidase. F Immunol 1986; 137: 2925-9.

50 Walsh C E, Waite B M, Thomas M J, De Chatelet L R. Release and metabolism of arachidonic acid in human Release and metabolism of arachidonic acid
neutrophils. $\mathcal{F}$ Biol Chem 1981; 256: 7228-34.

51 Sircar J C, Schwender C F, Carethers M E. Inhibition of soybean lipoxygenase by sulfasalazine and 5 -aminosalicylic acid: a possible mode of action in ulcerative colitis. Biochem Pharmacol 1983; 32: 170-2.

52 Allgayer H, Eisenburg J, Paumgartner G. Soybean lipoxygenase inhibition: studies with the sulphasalazine metabolites sulphapyridine. Eur 7 Clin Pharmacol 1984; 26: 449-51.

53 Stenson W F, Lobos E. Sulfasalazine inhibits the synthesis of chemotactic lipids by neutrophils. $\mathcal{F}$ Clin Invest 1982; 69: 494-7. 